\title{
Mechanisms Underlying the Protective Potential of $\alpha$-Tocopherol (Vitamin E) against Haloperidol-associated Neurotoxicity
}

\author{
Anke Post, M.D., Monika Rücker, B.Sc., Frauke Ohl, Ph.D, Manfred Uhr, M.D.,
} Florian Holsboer, Ph.D., M.D., Osborne F. X. Almeida, Ph.D., and Theologos M. Michaelidis, Ph.D.

The undesired side-effects of haloperidol treatment include a number of extrapyramidal side-effects which have been proposed to result from drug-induced damage to the basal ganglia. The drug also causes irregular movements and locomotor patterns in experimental animals. Here we show that haloperidol treatment in rats is associated with increases in the expression of $p 53$ and the ratio of pro-apoptotic (Bax) to anti-apoptotic $\left(B c l-2 / B c l-x_{L}\right)$ proteins in the hippocampus and caudate putamen (CPu). In addition, haloperidol induces the DNA binding activity of the redox-sensitive nuclear factor-kappa $B(N F-\kappa B)$ and concomitantly upregulates the levels of the phosphorylated form of $I \kappa B \alpha$ protein in vivo. Similar responses are observed when a mouse hippocampal cell line (HT-22) is treated with haloperidol and/or vitamin E. Interestingly, all of these biochemical effects of haloperidol are significantly attenuated when animals or cultured cells are pretreated with $\alpha$-tocopherol (vitamin E). Consistent with this, vitamin $E$ is demonstrated to substantially reduce the haloperidol-induced impairment of locomotor activity in rats. Collectively, the data indicate the usefulness of vitamin $E$ as an adjunct to haloperidol treatment and provide initial clues about the underlying molecular mechanisms involved in these effects.

[Neuropsychopharmacology 26:397-407, 2002]

(C) 2002 American College of Neuropsychopharmacology.

Published by Elsevier Science Inc.
KEY WORDS: Haloperidol; NF- $\kappa B / I \kappa-B ; p 53 ;$ Apoptosis; Bax; Tardive dyskinesia

Haloperidol, a typical member of the conventional neuroleptics, is thought to exert its clinical effect through striatal dopamine D2-receptors (Creese et al. 1976) and $\sigma$-receptors (Walker et al. 1990; Vilner et al. 1995). The

From the Max Planck Institute of Psychiatry, 80804 Munich, Germany

Address correspondence to: Anke Post, M.D., Max Planck Institute of Psychiatry, Kraepelinstr. 2-10, D-80804 Munich, Germany, Tel.:+49-89-30622-554, Fax: +49-89-30622-461, E-mail: post@mpipsyk1. mpg.de

Received April 5, 2001; revised August 20, 2001; accepted September 7, 2001.

Online publication: 9/11/01 at www.acnp.org/citations/Npp 091101173 neuroleptic efficacy of haloperidol in psychotic patients is somewhat compromised by the drug's liability to cause acute and chronic extrapyramidal side-effects, including tardive dyskinesia (TD). Haloperidol and its metabolites also produce abnormal movements in animals, e.g. oral dyskinesia, which has been associated with morphological alterations in distinct brain regions, namely the striatum and the nucleus basalis of Meynert (Meshul and Tan 1994; Kelley et al. 1997; Halliday et al. 1999; for review see also: Andreassen and Jorgensen 2000). Oxidative stress, resulting from alterations of the mitochondrial electron transport chain, has been proposed as one possible pathogenic mechanism of neuroleptic-induced TD (Cadet et al. 1986; Cadet and Kahler 1994; Elkashef and Wyatt 1999; Casey 2000). Indeed, we and others recently showed that haloperidol-induced 
neuronal damage is, at least partly, accounted for by its stimulation of reactive oxygen species (ROS) formation and reductions in the intracellular concentrations of glutathione (Shivakumar and Ravindranath 1992, 1993; Behl et al. 1995; Sagara 1998; Post et al. 1998; Yokoyama et al. 1998). In addition, there is growing evidence for an increase in excitotoxic glutamate release relatively soon after the onset of haloperidol treatment (See and Chapman 1994; See and Lynch 1995; Hussain et al. 2001).

In view of the above, strategies to reduce the oxidative stress load, e.g. by co-administration of free radical scavengers such as $\alpha$-tocopherol (vitamin E), would seem a reasonable approach to minimize the unwanted side-effects of haloperidol treatment. In previous in vitro studies we demonstrated the ability of vitamin $\mathrm{E}$ to counteract the cytotoxic effects of haloperidol (Post et al. 1998). However, a series of clinical studies in which the effects of vitamin $\mathrm{E}$ in patients with haloperidolassociated TD was investigated yielded an inconclusive picture with respect to efficacy of the anti-oxidant. For example, while beneficial effects of vitamin $\mathrm{E}$ were reported in a subgroup of patients with TD (for review see: Boomershine et al. 1999; Gupta et al. 1999), the results of a longterm study failed to provide such supporting evidence (Adler et al. 1999). It should be noted, however, that in all of the above-cited investigations, intervention with vitamin E was initiated after manifestation of the movement disorders. Interestingly, Gattaz et al. (1993) found that concomitant treatment with vitamin E counteracted haloperidol-induced hypersensitivity to apomorphine, and Takeuchi et al. (1998) showed that vitamin E co-administration suppresses chewing movements and buccal tremor in haloperidol-treated rats.

In the present study, we investigated some of the mechanisms that may underlie haloperidol-associated neuronal damage and the attenuation of this phenomenon by vitamin $\mathrm{E}$ ( $\alpha$-tocopherol). The studies were carried out in rats as well as in the hippocampal cell line HT-22 in order to permit extrapolations from one model to another. Specifically, we examined alterations in the DNA-binding activity of the redox-sensitive transcription factor NF- $\mathrm{\kappa B}$ and the phosphorylated state of its inhibitory partner IкB $\alpha$, as well as the expression levels of the major pro- (Bax) and anti-apoptotic (Bcl-2; $\mathrm{Bcl}-\mathrm{x}_{\mathrm{L}}$ ) proteins after the administration of haloperidol and vitamin $\mathrm{E}$ alone or in combination. In the in vivo experiments, we focused these analyses on the hippocampus and the $\mathrm{CPu}$; both these structures are involved in neuroleptic-induced behavior and structural changes as well as in the pathology of schizophrenia (Ramaekers et al. 1999; Harvey and Keefe 2001; Kuperberg and Heckers 2000). Further, we examined whether vitamin E pretreatment can attenuate haloperidol-induced anxiety and disturbances in locomotor behavior. Our results support a potential therapeutic role for vitamin $\mathrm{E}$ in overcoming the negative effects of haloperidol treatment and provide evidence that apoptosis may underlie some of the undesired effects of haloperidol.

\section{MATERIALS AND METHODS}

\section{Cell Culture}

HT-22 cells, a kind gift from Dr. P. Maher (La Jolla, CA), were cultured in Dulbeccos's modified Eagle's medium (DMEM) supplemented with $10 \%$ fetal calf serum (FCS) according to a standard protocol (Maher and Davis 1996). Haloperidol for in vitro experiments was obtained from RBI Biochemicals (Biotrend, Köln, Germany). The $\alpha$-tocopherol (vitamin E) was purchased from Sigma Chemicals (Deisenhofen, Germany). Generally, $10-\mathrm{cm}$ dishes of HT-22 cells $\left(1 \times 10^{6}\right)$ were treated with haloperidol at the doses and for the times indicated. The drugs were prepared as $10 \mathrm{mM}$ stock solutions in absolute ethanol. The amount of the solvent proved not to affect cell viability or other parameters tested in this study.

\section{Animals}

The animal studies were conducted in accordance with the Guide for the Care and Use of Laboratory Animals of the Government of Bavaria, Germany. Male Wistar rats $(250 \pm 10 \mathrm{~g} \mathrm{BW}$ at the beginning of the study; $\mathrm{n}=$ 27) were housed in groups of 5-6 under standard laboratory conditions $(12: 12 \mathrm{~h}$ light/dark cycle with lights on at 7:00 A.M., $22 \pm 1^{\circ} \mathrm{C}, 60 \%$ humidity, pelleted food and water ad libitum).

\section{Treatments}

The animals ( $n=5-6$ per group) were given one of four treatment conditions over a period of 14 or 7 days: (1) controls: intraperitoneal (i.p.) saline $(0.5 \mathrm{ml} ; 14$ days $)+$ subcutaneous (s.c.) sesame oil ( $0.5 \mathrm{ml} ; 14$ days); (2) haloperidol (HP) Janssen, Beerse, Belgium; $1 \mathrm{mg} / \mathrm{kg}$, i.p., 7 days)/sesame oil (s.c., 14 days); (3) saline (i.p., 14 days) $/ \alpha$-tocopherol acetate (vitamin E dissolved in sesame oil, sc., 14 days); (4) HP (Janssen; $1 \mathrm{mg} / \mathrm{kg}$, i.p., 7 days) $/ \alpha$-tocopherol (Sigma; dissolved in sesame oil, sc., 14 days). HP was applied at a dose of $1 \mathrm{mg} / \mathrm{kg}$ BW; this dose was based on previous studies in rats (Fischer et al. 1998; Schmitt et al. 1999), and was shown to result in serum levels of the drug which are comparable to those found in humans receiving the medication (Baldessarini et al. 1988; Volavka et al. 1995). $\alpha$-Tocopherol did not affect significantly the cerebral (cerebellum) HP levels (HP-treated animals $=147 \pm 17 \mathrm{ng} / \mathrm{mg}$ versus Vita$\mathrm{min} / \mathrm{HP}$-treated animals $=128 \pm 12 \mathrm{ng} / \mathrm{mg}$ ) as measured by LCMS. Animals were pretreated for seven days with $\alpha$-tocopherol acetate/sesame oil before being 
co-administered haloperidol and $\alpha$-tocopherol for a further seven days. The $\alpha$-tocopherol dose was derived from those used in human clinical studies (Barak et al. 1998; Gupta et al. 1999; Boomershine et al. 1999). As measured by HPLC, the levels of $\alpha$-tocopherol in plasma and brain homogenates of vitamin E-treated animals were markedly increased at the time of sacrifice (day 15).

\section{Behavioral Assessment}

Behavioral testing was performed on the penultimate day of the experiment, i.e. seven days after commencement of haloperidol treatment. To avoid the confounding sedative and cataleptic actions of haloperidol, behavioral testing was carried out $3-4 \mathrm{~h}$ after the administration of haloperidol. Briefly, rats were placed for $5 \mathrm{~min}$ in an empty plexiglass cage $(58 \times 38 \times 20 \mathrm{~cm})$ on top of a a grid and locomotor activity (number of line crossings) was assessed. The latency until an animal displayed immobility was noted as an additional indicator for general activity. Stretched attends (stretched body posture), representing risk assessment behavior in rats (cf. Cruz et al. 1994; Griebel et al. 1997) were scored as an indicator of anxiety. All behavioral observations were performed by trained and experienced observers.

\section{Tissue Preparation}

Animals were killed between 1 and 2 P.M., eight days after first exposure to haloperidol. At sacrifice, trunk blood and brains were collected. The hippocampus and caudate putamen $(\mathrm{CPu})$ were carefully dissected out and immediately transferred to liquid nitrogen until the time of biochemical or histochemical analysis.

\section{Western Blot Analysis}

Cells treated in vitro were washed in PBS and lysates were prepared using standard methods. Rat tissues were processed according to previously-described procedures (Krajewski et al. 1995). For both, equal amounts of protein were resolved on a $8 \%$ SDS-polyacrylamide gel, before transfer to PVDF transfer membranes (Amersham, Braunschweig, Germany). Membranes were subsequently incubated with antibodies against Bax, Bcl-2, Bcl-x L $_{\text {L }}$ (Santa Cruz Biotechnology, Heidelberg, Germany), or p53 (Oncogene, Bad Soden, Germany); in all cases, membranes were also incubated with antiactin (Chemicon, Hofheim, Germany). After overnight incubation at $4^{\circ} \mathrm{C}$, blots were washed with TBST buffer before incubation with a horseradish peroxidase linked antibody ( $1 \mathrm{~h}$, room temperature) and visualized by the ECL-detection kit (Amersham). Blot intensities were measured (arbitrary optical density units) using the software TINA (v. 2.0), and values for the proteins of interest were normalized with respect to those obtained for actin.

\section{TUNEL Staining}

For this, HT-22 cells were grown on glass coverslips. The protocol followed was adapted from Gavrieli et al. (1992), as described in Post et al. (2000). Cryosections $(20 \mu \mathrm{m})$ from the hippocampus and CPu were also processed for TUNEL histochemistry, using a previouslypublished protocol (Hassan et al. 1996). TUNEL-stained cells and non-labeled healthy cells were counted in representative fields following strict morphological criteria (see Post et al. 2000), and an apoptotic index was derived from the ratio of TUNEL-positive to total number of cells in each field. Five readings were obtained for each treatment condition.

\section{Electrophoretic Mobility Shift Assay (EMSA)}

The DNA binding activity of NF- $\mathrm{B}$ was studied using EMSA as described previously (Post et al. 1998, 2000). Nuclear extracts were prepared by a mini-extraction protocol (Schreiber et al. 1989). For competition assay, 20-fold molar excess unlabeled NF- $\kappa$ B oligonucleotide was added $45 \mathrm{~min}$ pior to addition of the labeled probe. The specificity of the complexes was further determined by supershift experiments using $10 \mu \mathrm{g}$ of the nuclear extracts and $1 \mu \mathrm{l}$ of anti-p65 antibody stocks (Santa Cruz Biotechnology, Heidelberg, Germany). DNAprotein complexes were analyzed by electrophoresis on $6 \%$ polyacrylamide gels. The binding activity of NF- $\mathrm{kB}$ (arbitrary optical density units) was quantified by scanning the autoradiographies using the software TINA (v. 2.0).

\section{Statistical Analysis}

Data were analyzed by 1-way analysis of variance and appropriate post hoc tests. $P$ values $\leqslant .05$ were considered significant.

\section{RESULTS}

\section{Haloperidol Induces Apoptosis in HT-22 Cells}

As shown in Figure 1, Panel A, treatment of HT-22 cells with haloperidol resulted in a significant increase in the number of cells undergoing apoptosis as judged by TUNEL staining. In a previous study (Post et al. 1998), HT-22 cell viability was also demonstrated to be compromised after exposure to haloperidol (at doses ranging between 1 and $100 \mu \mathrm{M}$ ); the present data indicate that apoptotic pathways account for at least some of the cell death observed following treatment with 
the neuroleptic. Significant changes in the number of TUNEL-positive cells were not detectable in the hippocampus and $\mathrm{CPu}$ of haloperidol-treated rats (data not shown).

\section{Haloperidol Alters the Expression of Apoptosis- related Molecules in vitro and in vivo}

Alterations in the protein levels of two major apoptosis-related molecules, Bax and Bcl-2, supported the view that apoptotic mechanisms, at least partly, account for the cytotoxic effects of haloperidol in HT-22 cells. As shown in Figure 1, Panel B, haloperidol-challenged HT-22 cells exhibited an increased Bax to Bcl-2 expression ratio as compared with non-treated cells. Further, haloperidol treatment led to a $>2$-fold increase in the expression of the tumor suppressor protein p53 (Figure 1, Panel B), a regulator of the bax and

A HT-22 cells
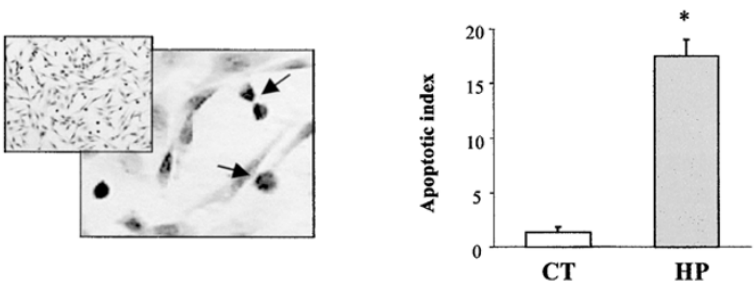

B
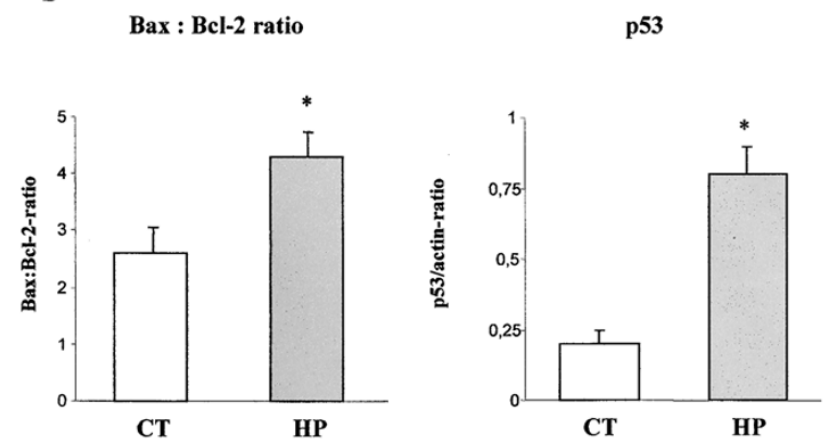

Figure 1. Panel A: DNA fragmentation in HT-22 cells after addition of haloperidol as detected by TUNEL staining. Panel A, left: Representative phase contrast micrographs $(\times 100$, $\times 200$ ) show the morphology of cells after exposure to $50 \mu \mathrm{M}$ haloperidol for $2 \mathrm{~h}$. Arrowheads indicate cells scored as apoptotic. Panel A, right: Apoptotic index (mean \pm SEM) derived from five fields per cell preparation in two independent experiments. ${ }^{*} p<.05$ vs. control. Panel B. Effects of haloperidol (HP) on cell death-related protein level in HT-22 cells. HP increases the Bax/ $\mathrm{Bcl}-2$ ratio and the $\mathrm{p} 53$ protein levels in HT22 cells. Cells were treated with $50 \mu \mathrm{M}$ of HP for $20 \mathrm{~h}$ and 20 $\mu \mathrm{g}$ protein extracts were subjected to Western blot analysis. The data (four independent experiments) are shown as a ratio $\left( \pm\right.$ SEM) to actin protein values, ${ }^{*} p<.05$. bcl-2 genes (Miyashita et al. 1994; Miyashita and Reed 1995).

Data obtained on the expression profiles of pro- and anti-apoptotic molecules in the hippocampus and $\mathrm{CPu}$ of haloperidol-treated rats are illustrated in Figure 2, Panel A. Consistent with the in vitro observations described above, haloperidol significantly increased the ratio of $\mathrm{Bax}$ versus the anti-apoptotic protein $\mathrm{Bcl}-\mathrm{x}_{\mathrm{L}}$. Likewise, haloperidol treatment led to a significant increase in the expression of p53 in both the hippocampus (3.8-fold) and $\mathrm{CPu}$ (3.5-fold) (Figure 2, Panel B). Collectively, the results indicate that haloperidol influences the expression of critical apoptosis-related molecules in the rat hippocampus and $\mathrm{CPu}$, brain regions which are respectively associated with behavioral functions and the coordination of motor movements.
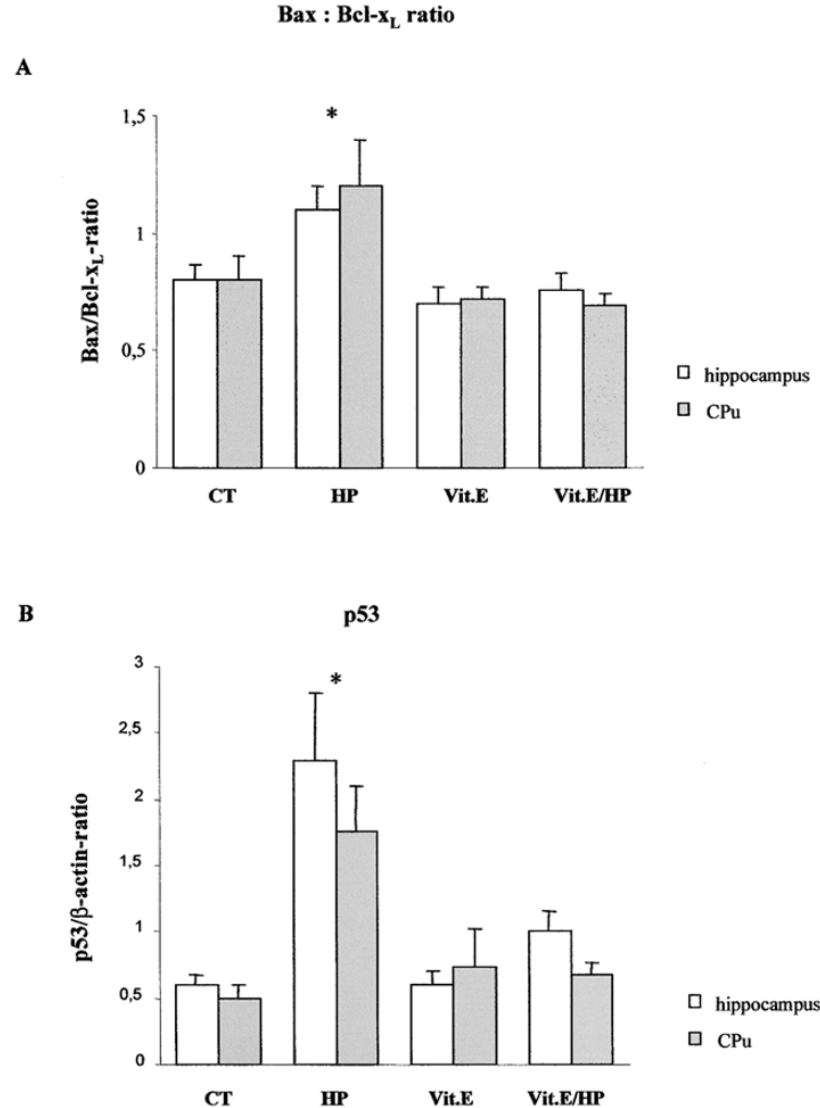

Figure 2. Effects of haloperidol (HP) and vitamin E/HP on cell death-related protein level in vivo. $\mathrm{HP}$ increases the $\mathrm{Bax} / \mathrm{Bcl}-\mathrm{x}_{\mathrm{L}}$ ratio (Panel A) and the p53 protein (Panel B) levels in the hippocampus and the caudate putamen $(\mathrm{CPu})$. Rats were treated with $\mathrm{HP}$ ( $1 \mathrm{mg} / \mathrm{kg}$ body weight per day) and the levels for Bax, Bcl- $x_{\mathrm{L}}$ and p53 proteins in the hippocampus and $\mathrm{CPu}$ were determined by Western blot analysis (30 $\mu$ g protein). The data are expressed as mean \pm SEM ( $\mathrm{n}=$ 5 animals per group), ${ }^{*} p<.05$ between HP and control group. In all cases, semi-quantitative values of protein expression levels are normalized relative to actin staining. 


\section{Haloperidol Increases the DNA-binding Activity of NF-kB and Upregulates the Phoshorylated Form of I $\mathrm{I} B \alpha$ in Hippocampus and CPu}

Previous studies provided evidence that haloperidol (and/or its metabolic derivatives) can lead to detrimental changes in the redox potential of HT-22 cells, accompanied by an increase in intracellular peroxides and decrease in glutathione levels. Importantly, this treatment also resulted in a dramatic induction of the DNA-binding and transcriptional activity of the redoxsensitive transcription factor NF- $\mathrm{kB}$ (Post et al. 1998). We therefore examined whether exposure to haloperidol can lead to a similar induction of NF- $\kappa$ B activity in vivo. The activity of NF-кB was monitored by EMSA, using nuclear extracts from different regions of the brain and a radiolabeled double-stranded oligonucleotide containing the NF- $\kappa \mathrm{B}$ consensus sequence. As shown in Figure 3, Panel A, haloperidol significantly increased the DNA-binding activity of NF- $\kappa B$ of this transcription factor in the rat hippocampus and $\mathrm{CPu}$. The specificity of the induced complex was confirmed by supershift experiments using an antibody against the p65 component of NF-кB (Figure 3, Panel A, right).

To further investigate the mechanism by which haloperidol influences NF- $\kappa \mathrm{B}$ activation we examined the phosphorylation state and protein levels of IкB $\alpha$, the endogenous inhibitor of NF-кB activation. Phosphorylation of $\mathrm{I} \kappa \mathrm{B} \alpha$ leads to its ubiquitination and subsequent degradation, resulting in the nuclear translocation of NF- $\kappa \mathrm{B}$ and its activation of transcription. Western blot analysis revealed that haloperidol significantly upregulates the levels of the Ser32-phoshorylated IкB $\alpha$ levels in both the hippocampus (2.8-fold) and the $\mathrm{CPu}(1.8$ fold) (Figure 3, Panel B), in keeping with the above findings on NF- $\mathrm{kB}$.

\section{Vitamin E ( $\alpha$-tocopherol) Abolishes the Effects of Haloperidol on the Expression of Apoptosis-related Molecules and Activation of NF-кB}

In agreement with our previous findings (Post et al. 1998), pre-treatment with the anti-oxidant $\alpha$-tocopherol (vitamin E) markedly attenuated the neurotoxic effects of haloperidol on HT-22 cells (data not shown). In keeping with these in vitro findings, we observed that vitamin $\mathrm{E}$ abolished the haloperidol-induced increases in the levels of p53 and Bax:Bcl- $x_{\mathrm{L}}$ ratios in hippocampus and $\mathrm{CPu}$; vitamin $\mathrm{E}$ on its own did not alter these parameters (Figure 2).

Similarly, administration of vitamin E significantly reduced the haloperidol-mediated increase in the DNAbinding activity of NF- $\mathrm{KB}$ as well as the phosphorylation state of $I \kappa B \alpha$ (Figure 3) in both the hippocampus and $\mathrm{CPu}$.
$\mathbf{A}$
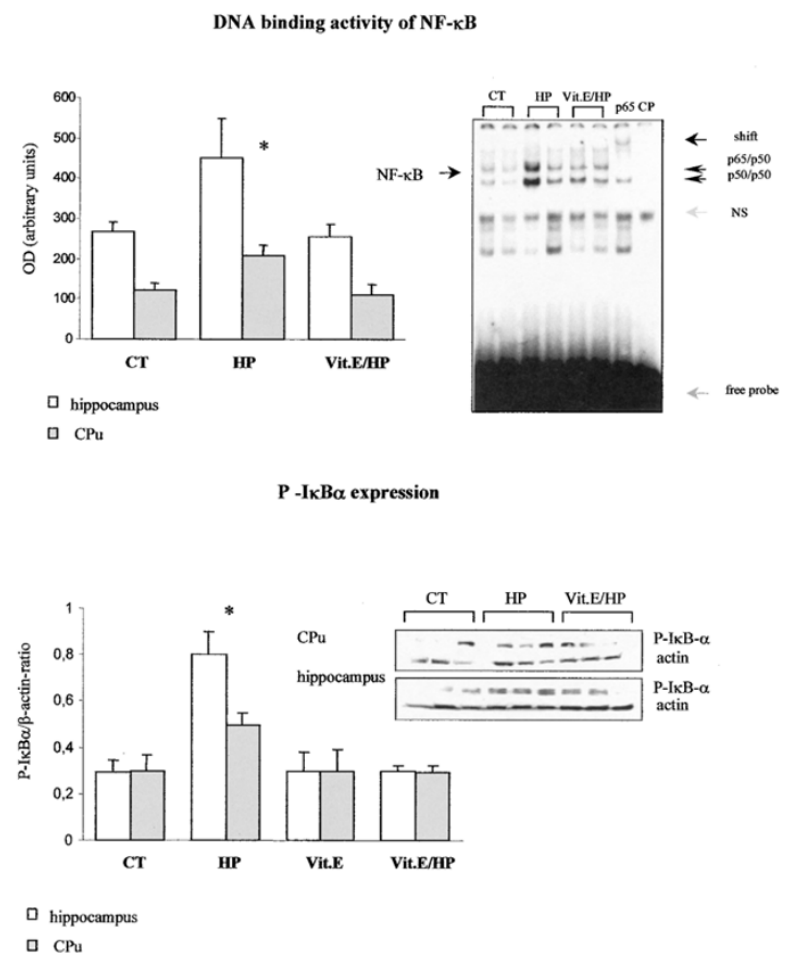

Figure 3. Panel A. Evaluation of the DNA binding activity of NF-кB by EMSA. Nuclear extracts $(10 \mu \mathrm{g})$ from hippocampus and $\mathrm{CPu}$ of control (CT)-, haloperidol (HP)- and vitamin E/haloperidol (Vit.E/HP)-treated rats were assayed for binding to an oligonucleotide containing the NF- $\kappa$ B consensus sequence. A representative analysis of the hippocampus is shown. Supershift experiments with anti-p65 demonstrate that the low mobility protein complex interacting with the NF-кB oligonucleotide contains the p65 subunit (lane 7). For competition (CP), an excess of unlabeled oligonucleotide was used (lane 8). The position of the specific and non-specific complexes is indicated by black and gray arrowheads, respectively. On the left panel, a semi-quantitative analysis of data from five animals is shown, ${ }^{*} p<.05$ between HP and Vit.E/HP group. Panel B. Levels of the phosphorylated form of IкB $\alpha$. Extracts ( $30 \mu \mathrm{g}$ protein) from hippocampus and $\mathrm{CPu}$ of rats treated as above were subjected to western blot analysis using antibodies against the Ser32-phosphorylated form of IкB $\alpha$. A semi-quantitative analysis of data from five animals, ${ }^{*} p<.05$ between HP and Vit.E/HP group is shown in the graph. On the right panel, Western blots of three animals per treatment group are shown as indicated.

\section{Vitamin E Abolishes the Haloperidol-induced Reduction of Locomotor Activity}

Haloperidol treatment in rats has been previously reported to result in reduced locomotor activity and an increase in anxiety-related behavior (Fischer et al. 1998; Grimm et al. 1998; Nowakowska et al. 1999; for review see also Andreassen and Jorgensen 2000). Here, animals receiving the combined vitamin E/haloperidol regimen dis- 
$\mathbf{A}$

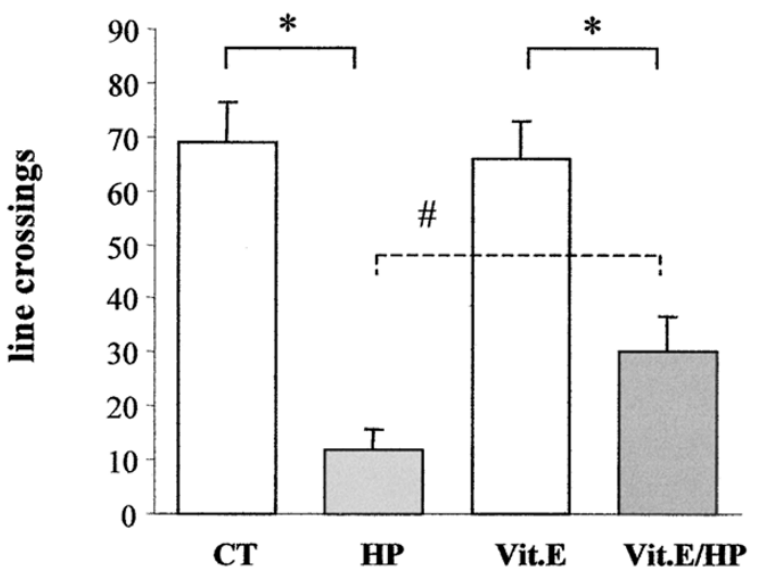

B

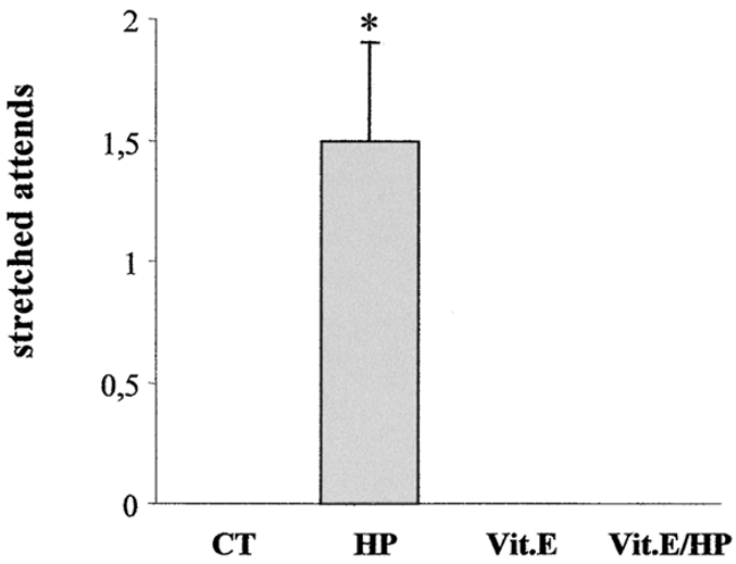

Figure 4. Behavioral parameters assessed in a novel environment under control $(\mathrm{CT})$, haloperidol $(\mathrm{HP})$, vitamin $\mathrm{E}$ (Vit.E), and vitamin E plus HP (Vit. E/HP) treatment conditions after seven days. Rats ( $\mathrm{n}=5$ per group) received haloperidol (1mg/kg BW/day) or haloperidol + vitamin E (100 IU/day). Number of line crossings, serving as an index of motor activity (Panel A), ${ }^{*} p=.054,{ }^{*} p<.05$; and stretched attends, serving as a measure of risk asssessment (Panel B), are shown. ${ }^{*} p<.05$.

played a higher number of line crossings compared with the animals treated with haloperidol alone (borderline significance, $p=.054$ ) when transfered to a novel environment (Figure 4, Panel A). These observations were matched by greater latency of immobility in the rats receiving vitamin $\mathrm{E}$ and haloperidol $(30.8 \mathrm{~s} \pm 12$ per $5 \mathrm{~min}$ vs. $55.5 \mathrm{~s} \pm 14$ per $5 \mathrm{~min}$ ). Further, as compared with animals exposed to haloperidol alone, those receiving the combination of haloperidol and vitamin $\mathrm{E}$ displayed no 'stretched attends', i.e. they displayed less anxiety (cf. Cruz et al. 1994; Griebel et al. 1997) (Figure 4, Panel B).

\section{DISCUSSION}

One purpose of this study was to investigate, in vivo, the molecular basis for the extrapyramidal side effects (e.g. tardive dyskinesia) associated with neuroleptic treatment. Another aim was to attempt to understand the mechanisms by which antioxidants, such as $\alpha$-tocopherol (vitamin E), might counteract these adverse effects. Previous studies have convincingly shown that neuroleptics can increase both the release of the excitotoxic transmitter glutamate (See and Chapman 1994; See and Lynch 1995; Hussain et al. 2001) and oxidative stress (Cadet et al. 1986; Tsai et al. 1998; Elkashef and Wyatt 1999; Casey 2000); both glutamate and oxidative stress are well known to precipitate neuronal damage or death (Halliwell 1992; Coyle and Puttfarcken 1993; Olanow 1993). Indeed, earlier studies from our own and other laboratories have demonstrated that exposure of neural cells to haloperidol in vitro results in increased free radical production and cell death (Behl et al. 1995; Post et al. 1998; Sagara 1998). Evidence that such mechanisms may also apply in vivo includes the observations that haloperidol treatment of rats leads to increased peroxide generation and lipid peroxidation in the striatum, and, concomitantly, reductions in brain levels of glutathione (Shivakumar and Ravindranath 1992, 1993; Yokoyama et al. 1998). Further, patients with neuroleptic-induced TD display signs of increased oxidative stress (elevated lipid peroxidation products and decreased superoxide dismutase activity) in the CSF (Lohr et al. 1988; Nagesh Pai et al. 1994; Brown et al. 1998; Tsai et al. 1998; for review see also Cadet and Kahler 1994). The implied role of free radicals in the neuropathology of TD has made the idea of attenuating the impact of free radicals an attractive proposition. Several studies, albeit with conflicting outcomes, have attempted to exploit the anti-oxidant properties of vitamin $\mathrm{E}$ to this end (Barak et al. 1998; Boomershine et al. 1999; Adler et al. 1999; Gupta et al. 1999). However, the outcomes of those studies have been inconclusive and, further, the biological basis for such therapy has not been adequately provided by the studies published to date.

\section{Biochemical and Morphological Manifestations of Haloperidol Treatment}

In this paper we show that haloperidol induces molecular events in the hippocampus and caudate putamen $(\mathrm{CPu})$ of rats which closely resemble those we previously observed in haloperidol-treated HT-22 cells (Post et al. 1998). The latter in vitro observations were confirmed in the present work. The biochemical changes included haloperidol-induced increases in the DNAbinding activity of the redox-sensitive transcription factor NF- $\mathrm{kB}$ and an increase in the phosphorylation state

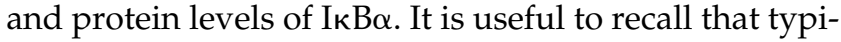
cally, NF- $\mathrm{B}$ is sequestered in the cytoplasm as homo- 
and heterodimers (Sen and Baltimore 1986), and its activation is strictly controlled by an endogenous inhibitor, ІкB (Baldwin 1996). Upon phosphorylation, IкB dissociates from NF- $\mathrm{B}$, allowing translocation of NF- $\kappa \mathrm{B}$ to the nucleus where it binds at specific NF-кB-responsive elements in regulatory DNA sequences of target genes. Earlier studies, including our own with haloperidol, demonstrated increases in the DNA-binding and transcriptional activity of NF- $\mathrm{BB}$ to be associated with decreased cell viability (Grilli et al. 1996; Lezoualc'h et al. 2000; Lipton 1997; Post et al. 1998, 2000). Further, we previously showed that overexpression of a mutated form of IкB $\alpha$ results in protection against haloperidolinduced neurotoxicity in HT-22 cells (Post et al. 1998). The present work shows that apoptosis, at least partly, accounts for the cell death seen after exposure of HT-22 cells to haloperidol. Apoptosis-inducing properties of haloperidol have also been described recently in primary neuronal cells (Galili-Mosberg et al. 2000; Noh et al. 2000).

In comparison to studies on cell culture models (Behl et al. 1995; Post et al. 1998; Sagara 1998; Galili-Mosberg et al. 2000; Noh et al. 2000), there is a paucity of data to support the view that haloperidol treatment results in neuronal cell death in vivo. Notably, however, histopathologic changes have been reported after chronic administration (weeks to months) of haloperidol to experimental animals (Meshul et al. 1994, 1996; Andreassen et al. 1998; for review see Miller and Chouinard 1993; Andreassen and Jorgensen 2000), although inconsistent reports for both animals and humans also exist (Christiansen et al. 1970; Kung et al. 1998; Eyles et al. 2000). Interestingly, also, a recent study provided morphological evidence that haloperidol treatment leads to increased excitotoxic (glutamergic) activity in the striatum (Andreassen et al. 2001). Further, insofar that changes in neurotrophin expression may serve as indices of neuronal damage and repair, haloperidol was shown to decrease levels of brain-derived neurotrophic factor and nerve growth factor in the rat hippocampus and striatum (Angelucci et al. 2000; Dawson et al. 2001). In the in vivo part of the present study, despite the above-mentioned alterations in NF- $\mathrm{\kappa B}$ activity, TUNEL histochemistry failed to reveal apoptotic cells in either the hippocampus or $\mathrm{CPu}$ of haloperidol-treated rats. Several reasons might be proposed for the absence of apoptotic cells, e.g.: apoptotic cells are usually rapidly cleared away by macrophages; only a small sub-population of neurons might be affected, thus evading detection; or the duration of treatment (one week vs. several weeks to months in most previously published in vivo studies) (Andreassen et al. 2001; Angelucci et al. 2000; Dawson et al. 2001) may have been too short to permit visualization of apoptotic cells.

Importantly, despite our failure to visualize cells undergoing apoptosis, our analysis of key pro- and anti-apoptotic molecules strongly suggests that haloperidol can turn on the apoptotic machinery in cells of the hippocampus and the $\mathrm{CPu}$. Specifically, we found that haloperidol increases the ratio between the pro-apoptotic protein Bax and the anti-apoptotic protein $\mathrm{Bcl}-\mathrm{x}_{\mathrm{L}}$ in vivo (Bcl-2 was undetectable in the samples obtained from the in vivo experiments, in keeping with our previous findings in adult rats-see Almeida et al. (2000)); the ratio between Bax and the anti-apoptotic Bcl-2 was similarly altered in HT-22 cells exposed to the neuroleptic. Indeed, it is pertinent to mention that previous work, in which bcl-2 was overexpressed in HT-22 cells, demonstrated a protective role for $\mathrm{Bcl}-2$ against haloperidol toxicity (Lezoualc'h et al. 1996).

The link between these downstream events and those occurring earlier may be provided by p53 which has been shown to mediate oxidative stress-induced apoptosis in a Bcl-2-antagonizable fashion ( $\mathrm{Li}$ et al. 1999). Also, there is evidence that p53 can directly inhibit Bcl-2 expression (Miyashita et al. 1994; Fulci and Van Meir 1999) while activating bax (Miyashita and Reed 1995). The apoptotic actions of p53 (Fuchs et al. 1998; Fulci and Van Meir 1999), reportedly involve interactions with other transcription factors, including NF-кB (Wu and Luzano 1994; Grilli and Memo 1999; Webster and Perkins 1999; Ryan et al. 2000), and there is evidence that NF-кB can upregulate p53 in the striatum (Qin et al. 1999). Data obtained in the present investigation show that levels of p53 are upregulated by haloperidol in the rat hippocampus and the $\mathrm{CPu}$. Collectively, the obtained data on NF-кB activation, p53, and pro- and anti-apoptotic members of the Bcl-2 family indicate that haloperidol can initiate a cascade of molecular events which would be predicted to result in cell death. In order to resolve this apparent discrepancy between the biochemical and morphological observations, we recently initiated a study in which haloperidol will be administered chronically over several months; at the end of the study, brains will be systematically analyzed for neurodegeneration (including apoptosis) and total cell numbers in relevant brain areas will be assessed using stereological tools.

\section{Prophylactic Properties of Vitamin E Demonstrated at the Molecular Level}

The rationale behind attempts to counteract the adverse effects of haloperidol using anti-oxidants such as $\alpha$-tocopherol (vitamin E) have been discussed in the introduction. As mentioned earlier, clinical studies yielded equivocal results and further, a cellular and molecular basis for the efficacy of vitamin $\mathrm{E}$ as a protective agent has been lacking hitherto. Interestingly, pre- and concomitant administration of vitamin $\mathrm{E}$ was here shown to reverse all of the biochemical changes associated 
with haloperidol treatment. Specifically, vitamin E preand co-treatment significantly attenuated the induction of DNA-binding of the redox-sensitive factor NF- $\mathrm{B}$ and upregulation of p53 levels by haloperidol. Further, vitamin E pre- and co-treatment was shown to counteract the effects of haloperidol on members of the Bcl-2 family of molecules; specifically, in the presence of vitamin E, the cell death/survival molecule expression ratios are such that cell survival is ensured (Oltvai et al. 1993; Yin et al. 1994; Sedlak et al. 1995; Almeida et al. 2000). The signal transduction pathways underlying the interaction of oxidative stress-induced cell death and vitamin $\mathrm{E}$ (and analogs) function are currently the subject of active research (cf. Brigerius-Flohé and Traber 1999; Park et al. 2000; Sen et al. 2000). The available data indicate that the downstream molecules and pathways include NF- $\mathrm{KB}$, p38 and c-Jun- $\mathrm{NH}_{2}$-terminal protein kinase (JNK) and p53. These various components are intricately inter-connected (Suzuki and Packer 1993; Wu and Luzano 1994; Fuchs et al. 1998; Grilli and Memo 1999; Webster and Perkins 1999; Mielke and Herdegen 2000; Noh et al. 2000; Ryan et al. 2000; Tournier et al. 2000) and ultimately converge to determine cell survival by influencing relative levels of the pro- and antiapoptotic Bcl-2-related proteins (Merry and Korsmeyer 1997). Thus, despite our present lack of evidence for haloperidol-induced apoptosis and its prevention by vitamin $\mathrm{E}$ in vivo, the data showing stimulation and inhibition of apoptotic and anti-apoptotic molecular cascades by haloperidol and vitamin E, respectively, strongly indicate that haloperidol treatment can lead to apoptosis in the hippocampus and $\mathrm{CPu}$ in a vitamin E-antagonizable fashion. Indeed, the presently-reported in vitro observations on HT-22 cells support this conclusion.

\section{Vitamin E Attenuates Some Adverse Behavioral Effects Associated with Haloperidol Treatment}

As compared with risperidone and clozapine, typical neuroleptic drugs, such as haloperidol, induce anxietyrelated behavior in rats (Fischer et al. 1998; Singh et al. 1997; Nowakowska et al. 1999) and dysphoria and anxiety in humans (Belmaker and Wald 1977; King et al. 1995; Ramaekers et al. 1999). In addition, haloperidol and its related drugs produce other undesired effects in humans, including impairments of locomotor abilities and abnormal orofacial movements (for review see: Marsden and Jenner 1980; Ellenbroek 1993); equivalent changes, in addition to memory deficits, have also been observed in rats (Egan et al. 1996; Grimm et al. 1998, Nowakowska et al. 1999; for review: Waddington 1990; Andreassen and Jorgensen 2000). All of these effects have been postulated to result in part from neuronal damage occurring as a result of increased generation of reactive oxygen species (Voigtlander et al. 1990; Shivaku- mar and Ravindranath 1993; Nagesh Pai et al. 1994; Post et al. 1998; Sagara 1998; Yokoyama et al. 1998; Tsai et al. 1998; Elkashef and Wyatt 1999; Noh et al. 2000). In view of the above molecular data linking haloperidol treatment with neuronal cell death, as well as our findings that the biochemical actions of haloperidol can be largely reversed by vitamin $\mathrm{E}$, it was of interest to know whether at least some of its untoward behavioral effects could also be attenuated by vitamin E treatment. Interestingly, we observed that vitamin E significantly attenuates haloperidol-induced impairments in locomotor activity and increases in anxiety-like behavior.

\section{CONCLUSIONS}

The results from the in vivo studies reported here provide the first demonstration of a link between haloperidol and oxidative stress, NF- $\mathrm{B}$ activation, upregulation of p53 and Bax. These changes, together with the herein reported observations of haloperidol-induced adverse behaviors, strongly suggest that haloperidol treatment may cause neuronal damage in limbic structures and parts of the basal ganglia. Furthermore, the present study shows that pre- and co-treatment with vitamin E interferes with the stimulation of apoptotic cascades by haloperidol and, in addition, attenuates some of the undesirable behavioral side-effects of the neuroleptic. In providing some of the first information on the molecular targets of haloperidol and vitamin E, our results demonstrate a convincing biochemical basis for employing antioxidants such as vitamin E as prophylactics/protectants against the untoward effects of typical neuroleptics such as haloperidol.

\section{REFERENCES}

Adler LA, Rotrosen J, Edson R, Lavori P, Lohr J, Hitzmann R, Raisch D, Caligiuri M, Tracy K (1999): Vitamin E treatment for tardive dyskinesia. Arch Gen Psychiatry 56:836-841

Almeida OFX, Condé GL, Crochemore C, Demeneix BA, Fischer D, Hassan AHS, Meyer M, Holsboer, Michaelidis TM (2000): Subtle shifts in the ratio between pro and antiapoptotic molecules after activation of corticosteroid receptors decide neuronal fate. FASEB 14:779-789

Andreassen OA, Ferrante RJ, Beal MF, Jorgensen HA (1998): Oral dyskinesias and striatal lesions in rats after longterm co-treatment with haloperidol and 3-nitropropionic acid. Neuroscience 87(3):639-648

Andreassen OA, Jorgensen HA (2000): Neurotoxicity associated with neuroleptic-induced oral dyskinesia in rats: implication for tardive dyskinesia. Prog Neurobiol 61: 525-541

Andreassen OA, Meshul CK, Moore C, Jorgensen HA (2001): Oral dyskinesias and morphological changes in rat stri- 
atum during long-term haloperidol administration. Psychopharmacology (Berl) 157:11-19

Angelucci F, Aloe L, Gruber SHM, Fiore M, Mathe AA (2000): Chronic antipsychotic factor and neuropeptide Y immunoreactivity and the distribution of choline acetyl transferase in rat brain regions. Int J Neuropsychopharm 3:13-25

Baldessarini RJ, Cohen BM, Teicher MH (1988): Significance level of neuroleptic dose and plasma level in the pharmacological treatment of psychoses. Arch Gen Psychiatry 45:79-91

Baldwin AS (1996): The NF-кB and IкB proteins: New discoveries and insight. Annu Rev Immunol 14:649-668

Barak Y, Swartz M, Shamir E, Stein D, Weizman A (1998): Vitamin $\mathrm{E}$ ( $\alpha$-tocopherol) in the treatment of tardive dyskinesia : a statistical meta-analysis. Ann Clin Psychiatry 10:101-105

Behl C, Rupprecht R, Skutella T, Holsboer F (1995): Haloperidol-induced cell death-mechanism and protection with vitamin E in vitro. NeuroReport 7:360-364

Belmaker RM, Wald D (1977): Haloperidol in normals. Brit J Psychiatry 131:222-223

Boomershine KH, Shelton PS, Boomershine JE (1999): Vitamin $\mathrm{E}$ in the treatment of tardive dyskinesia. Ann Pharmacother 33:1195-1202

Brigerius-Flohé R, Traber MG (1999): Vitamin E: function and metabolism. FASEB J 13:1145-1155

Brown K, Reid A, White T, Henderson T, Hukin S, Johnstone C, Glen A (1998): Vitamin E, lipids, and lipid peroxidation products in tardive dyskinesia. Biol Psychiatry 43: 863-867

Cadet JL, Lohr JB, Jeste DV (1986): Free radicals and tardive dyskinesia. TINS 3:107-108

Cadet JL, Kahler LA (1994): Free radical mechanisms in schizophrenia and tardive dyskinesia. Neurosci Behav R 18:457-467

Casey DE (2000): Tardive dyskinesia: pathophysiology and animal models. J Clin Psychiat 61:5-9

Christiansen E, Moller JE, Faurbrye A (1970): Neuropathological investigation of 28 brains from patients with dykinesia. Acta Pychiatr Scand 46:14-23

Coyle JT, Puttfarcken P (1993): Oxidative stress, glutamate, and neurodegenerative disorders. Science 262:689-695

Creese I, Burt D, Snyder SH (1976): Dopamine receptor binding predicts clinical and pharmocological potencies of antischizophrenic drugs. Science 192:481-483

Cruz APM, Frei F, Graeff FG (1994): Ethopharmacological analysis of rat behavior on the elevated plus-maze. Pharmacol Biochem Behav 49:171-176

Dawson NM, Hamid EM, Egan MF, Meredith G (2001): Changes in the pattern of brain-derived neurotrophic factor immunoreactivity in rat brain after acute and subchronic haloperidol treatment. Synapse 39:70-81

Egan MF, Ferguson J, Hyde TM (1996): Effects of rating parameters on assessment of neuroleptic-induced vacuous chewing movements. Pharmacol Biochem Behav 53:401-410

Elkashef AM, Wyatt RJ (1999): Tardive dyskinesia: possible involvement of free radicals and treatement with vitamin E. Schizophr Bull 25:731-740
Ellenbroek BA (1993): Treatment of schizophrenia: a clinical and preclinical evaluation of neuroleptic drugs. Pharmacol Ther 57:1-78

Eyles DW, Pond SM, Van der Schyf C, Halliday GM (2000): Mitochondrial ultrastructure and density in a primate model of persistent tardive dyskinesia. Life Sci 66:13451350

Fischer V, Schmitt U, Weigmann H, Keller B, Reuss S, Hiemke C, Dahmen N (1998): Chronical haloperidol and clozapine treatment in rats: differential RNA display analysis, behavioural studies and serum level determination. Prog Neuropsychopharmacol Biol Psychiatry 22:1129-1139

Fuchs SY, Adler V, Pincus MR, Ronai Z (1998): MEKK1/JNK signaling stabilizes and activates p53. Proc Natl Acad Sci USA 95:10541-10546

Fulci G, VanMeir EG (1999): p53 and the CNS. Mol Neurobiol 19:61-77

Galili-Mosberg R, Gil-Ad I, Weizman A, Melamed E, Offen D (2000): Haloperidol-induced neurotoxicity-possible implications for tardive dyskinesia. J Neural Transm 107: 479-490.

Gavrieli Y, Sherman Y, Ben-Sassan SA (1992): Identification of programmed cell death in situ via specific labelling of nuclear DNA fragmentation. J Cell Biol 119:493-501

Gattaz WF, Emrich A, Behrens S (1993): Vitamin E attenuates the development of haloperidol-induced dopaminergic hypersensitivity in rats: possible implications for tardive dyskinesia. J Neural Transm 92:197-201

Griebel G, Rodgers RJ, Perrault G, Sanger DJ (1997): Risk assessment behavior: Evaluation of utility in the study of 5-HT-related drugs in the rat elevated plus-maze test. Pharmacol Biochem Behav 57:817-827

Grilli M, Pizzi M, Memo M, Spano P (1996): Neuroprotection by aspirin and sodium salicylate through blockade of NF-кB activation. Science 274:1383-1385

Grilli M, Memo M (1999): Possible role of NF-кB and p53 in the glutamate-induced pro-apoptotic neuronal pathway. Cell Death Differ 6:22-27

Grimm JW, Kruzich PJ, See RE (1998): Emergence of oral and locomotor activity in chronic haloperidol-treated rats following cortical $N$-Methyl-D-Aspartate stimulation. Pharmacol Biochem Behav 60:167-173

Gupta S, Mosnik D, Black DW, Berry S, Marsand PS (1999): Tardive dyskinesia: review of treatments past, present and future. Ann Clin Psychiatry 11:257-266

Halliday GM, Pond SM, Cartwright H, McRitchie DA, Castagnoli N, Van der Shyf CJ (1999): Clinical and neuropathological abnormalities in baboons treated with HPTP, tetrahydropyridine analog of haloperidol. Exp Neurol 158:155-163

Halliwell B (1992): Reactive oxygen species and the central nervous system. J Neurochem 59:1609-1622

Harvey PD, Keefe RS (2001): Studies of cognitive change in patients with schizophrenia following novel antipsychotic treatment. Am J Psychiatry 158(2):176-184

Hassan AS, von Rosenstiel P, Patchev K, Holsboer F, Almeida OFX (1996): Exacerbation of apoptosis in the dentate gyrus of the aged rat by dexamethasone and the protective role of corticosterone. Exp Neurol 140:43-54 
Hussain N, Flumerfelt BA, Rajakumar N (2001) : Glutamatergic regulation of haloperidol-induced c-fos expression in the rat striatum and nucleus accumbens. Neuroscience 102: 391-9

Kelley JJ, Gao XM, Tamminga CA, Roberts RC (1997): The effect of chronic haloperidol treatment on dendritic spines in the rat striatum. Exp Neurol 146:471-478

King DJ, Burke M, Lucas RA (1995): Antipsychotic druginduced dysphoria. Br J Psychiatry 167:480-482

Krajewski S, Mai JK, Krajewska M, Sikorska M, Mossakowski MJ, Reed JC (1995): Upregulation of Bax protein levels in neurons following cerebral ischemia. J Neurosci 15:6364-6376

Kung L, Conley R, Chute DJ, Smialek J, Roberts RC (1998): Synaptic changes in the striatum of schizophrenic cases: a controlled postmortem ultrastructural study. Synapse 28:125-139

Kuperberg G, Heckers S (2000): Schizophrenia and cognitive function. Curr Opin Neurobiol 10:205-10

Lezoualc'h F, Rupprecht R, Holsboer F, Behl C (1996): Bcl-2 prevents hippocampal cell death induced by the neuroleptic drug haloperidol. Brain Res 738:176-179

Lezoualc'h F, Engert S, Berning S, Behl C (2000): Corticotrophin-releasing hormone-mediated neuroprotection against oxidative stress is associated with the increased release of non-amyloidogenic amyloid $\beta$ precursor protein and with the suppression of NF-кB. Mol Endo 14:147-159

Li PF, Dietz R, von Harsdorf R (1999): p53 regulates mitochondrial membrane potential through reactive oxygen species and induces cytochrome c-independent apoptosis blocked by Bcl-2. EMBO J 18:6027-6036

Lipton SA (1997): Janus faces of NF-кB: Neurodestruction versus neuroprotection. Nature Med 3:20-22

Lohr JB, Cadet JL, Lohr MA, Larson L, Wasli E, Wade L, Hylton R, Vidoni C, Jeste DV, Wyatt RJ (1988): Vitamin E in the treatment of tardive dyskinesia: The possible involvement of free radical mechanism. Schizophr Bull 14:291-296

Maher P, Davis J (1996): The role of monoamine metabolism in oxidative glutamate toxicity. J Neurosci 15:6394-6401

Marsden CD, Jenner P (1980): The pathophysiology of extrapyramidal side-effects of neuroleptic drugs. Psychol Med 10:55-72

Merry DE, Korsmeyer SJ (1997): Bcl-2 gene family in the nervous system. Ann Rev Neurosci 20:245-267

Meshul CK, Tan SE (1994): Haloperidol-induced morphological alterations ars associated with changes in calcium/calmodulin kinase II activity and the glutamate immunoreactivity. Synapse 18:205-217

Meshul CK, Andreassen OA, Allen C, Jorgensen HA (1996): Correlation of vacuous chewing movements with morphological changes in rats following 1-year treatment with haloperidol. Psychopharmacology 125: 238-247

Miller R, Chouinard G (1993): Loss of striatal cholinergic neurons as a basis for tardive and L-dopa-induced dyskinesias, neuroleptic-induced supersensitivity psychosis and refractory schizophrenia. Biol Psychiatry 34:713-738

Mielke K, Herdegen T (2000): JNK and p38 stress kinasesdegenerative effectors of signal transduction-cascades in the nervous system. Progr Neurobiol 61:45-60
Miyashita T, Krajewski S, Krajewska M, Wang HG, Lin HK, Lieberman DA, Hoffman B, Reed JC (1994): Tumor suppressor p53 is a regulator of bcl-2 and bax gene expression in vitro and in vivo. Oncogene 9:1799-1805

Miyashita T, Reed JC (1995): Tumor suppressor p53 is a direct transcriptional activator of the human bax gene. Cell 80:293-299

Nagesh Pai B, Janakiramaiah N, Gangadhar BN, Ravindranath V (1994): Depletion of glutathione and enhanced lipid peroxidation in the CSF of acute psychotics following haloperidol administration. Biol Psychiatry 36:489-491

Noh JS, Kang HJ, Kim EY, Sohn S, Chung YK, Kim SU, Gwag BJ (2000): Haloperidol-induced neuronal apoptosis: role of p38 and c-Jun-NH2-terminal protein kinase. J Neurochem 75:2327-2334

Nowakowska E, Chodera A, Kus K, Rybakowski J (1999): Some behavioural effects of risperidone in rats: comparison with haloperidol. Eur Neuropsychopharmacol 9: $421-426$

Olanow CW (1993): A radical hypothesis for neurodegeneration. Trends Neurosci 16:439-444

Oltvai ZN, Milliman CL, Korsmeyer SJ (1993): Bcl-2 heterodimerizes in vivo with a conserved homolog, Bax, that accelerates programmed cell death. Cell 74:609-619

Park SA, Choi KS, Huh K, Kim SU (2000): Cisplatin-induced cell death in mouse hybrid neurons is blocked by antioxidants through suppression of cisplatin-mediated accumulation of p53 but not of fas/fas ligand. J Neurochem 75:946-953

Post A, Holsboer F, Behl C (1998): Induction of NF-кB activity during haloperidol-induced oxidative toxicity in clonal hippocampal cells: suppression of NF- $\mathrm{B}$ and neuroprotection by antioxidants. J Neurosci 15:82368246

Post A, Crochemore C, Uhr M, Holsboer F, Behl C (2000): Differential induction of NF- $\kappa$ B activity and neural cell death by antidepressants in vitro. Eur J Neurosci 12:4331-4337

Qin ZH, Chen RW, Wang Y, Nakai M, Chuang DM, Chase TN (1999): Nuclear factor $\kappa B$ nuclear translocation upregulates c-Myc and p53 expression during NMDA receptor apoptosis. J Neurosci19: 4023-4033

Raemekers JG, Louwerens JW, Muntjawerff ND, Milius H, De Bie A, Rosenzweig P, Patat A, O'Hanlon JF (1999): Psychomotor, cognitive, extrapyramidal, and affective functions of healthy volunteers during treatment with an atypical (amisulpride) and a classic (haloperidol) antipsychotic. J Clin Psychopharmacol 19:209-221

Ryan KM, Ernst MK, Rice NR, Vousden KH (2000): Role of NF- $\mathrm{B}$ in $\mathrm{p} 53-\mathrm{mediated}$ programmed cell death. Nature 404:892-897

Sagara Y (1998): Induction of reactive oxygen species in neurons by haloperidol. J Neurochem 71:1002-1012

Schmitt U, Dahmen N, Fischer V, Weigmann H, Rao ML, Reuss S, Hiemke C (1999): Chronic oral haloperidol and clozapine in rats: a behavioural evaluation. Neuropsychobiology 39:86-91

Schreiber E, Matthias P, Müller MM, Schaffner W (1989): Rapid detection of octamer binding proteins with miniextracts, prepared from a small number of cells. Nucleic Acids Res 17:6419 
Sedlak TW, Oltvai ZN, Yang E, Wang K, Boise LH, Thompson CB, Korsmeyer SJ (1995): Multiple Bcl-2 family members demonstrate selective dimerizations with Bax. Proc Natl Acad Sci USA 92:7834-7838

See RE, Chapman MA (1994): Chronic haloperidol, but not clozapine, produces altered oral movements and increased extracellular glutamate in rats. Eur J Pharmacology 263:269-276

See RE, Lynch AM (1995): Chronic haloperidol potentiates stimulated glutamate release in caudate putamen, but not prefrontal cortex. NeuroReport 6:1795-1798

Sen R, Baltimore D (1986): Multiple nuclear factors interact with the immunoglobin enhancer sequences. Cell 46: 705-706

Sen CK, Khanna S, Roy S, Packer L (2000): Molecular basis of vitamin E action. J Biol Chem 275:13049-13055

Shivakumar BR, Ravindranath V (1992): Oxidative stress induced by administration of the neuroleptic drug halperidol is attenuated by higher doses of haloperidol. Brain Res 595:256-262

Shivakumar BR, Ravindranath V (1993): Oxidative stress and thiol modification induced by chronic administration of haloperidol. J Pharmacol Exp Ther 3:1137-1141

Singh Y, Jaiswal AK, Singh M, Bhattacharya SK (1997): Effect of prenatal haloperidol administration on anxiety patterns in rats. Ind J Exp Biol 35:1284-1290

Suzuki YJ, Packer L (1993): Inhibition of NF-кB activation by vitamin E derivatives. Biochem Biophys Res Commun 193:277-283

Takeuchi H, Ishigooka J, Kobayashi K, Watanabe S, Miura S (1998): Study on the suitability of a rat model for tardive dyskinesia and the preventive effects of various drugs. Prog Neuropsychopharmacol Biol Psychiat 22:679-691

Tournier C, Hess P, Yang DD, Xu J, Turner TK, Nimnual A, Bar-Sagi D, Jones SN, Flavell RA, Davis RJ (2000): Requirement of JNK for stress-induced activation of the cytochrome c-mediated death pathway. Science 288: 870-874
Tsai G, Goff DC, Wang RW, Flood J, Baer L, Coyle JT (1998): Markers of glutamatergic neurotransmission and oxidative stress associated with tardive dyskinesia. Am J Psychiatry 155:1207-1213

Vilner BJ, Costa BR, Bowen WD (1995): Cytotoxic effects of sigma ligands: Sigma receptor-mediated alterations in cellular morphology and viability. J Neurosci 15:117-134

Voigtlander PF, Burian MA, Althaus JS, Williams LR (1990): Effects of chronic haloperidol on vitamin E levels and monoamine metabolism in rats fed normal and vitamin E deficient diets. Res Commun Chem Pathol Pharmacol 68:343-352

Volowka J, Cooper TB, Czobor P, Meisner M (1995): Plasma haloperidol levels and clinical effects in schizophrenia and schizoaffective disorder. Arch Gen Psychiatry 52: 837-845

Waddington JL (1990): Spontaneous orafacial movements induced in rodents by very long-term neuroleptic drug administration: phenomenology, pathophysiology and putative relationship to tardive dyskinesia. Psychopharmacology 101:431-447

Walker JM, Bowen WD, Walker FO, Matsumoto RR, De Costa B, Rice CK (1990): Sigma receptors: biology and function. Pharmacol Rev 42:355-402

Webster GA, Perkins ND (1999): Transcriptional cross talk between NF- $\kappa$ B and p53. Mol Cell Biol 19:3485-3495

Wu H, Lozano G (1994): NF-кB activation of $\mathrm{p} 53$, a potential mechanism for suppressing cell growth in response to stress. J Biol Chem 269:20067-20074

Yin XM, Oltvai ZN, Korsmeyer SJ (1994): BH1 and BH2 domains of $\mathrm{Bcl}-2$ are required for inhibition of apoptosis and heterodimerization with Bax. Nature 369:321-323

Yokoyama H, Kasai N, Ueda Y, Niwa R, Konaka R, Mori N, Tsuchihashi N, Matsue T, Ohya-Nishiguchi H, Kamada $H$ (1998): In vivo analysis of hydrogen peroxide and lipid radicals in the striatum of rats under long-term administration of a neuroleptic. Free Rad Biol Med 24:1056-1060 